\title{
Rural Crime from A Global Perspective ${ }^{1}$
}

Dr. Ralph A. Weisheit

Department of Criminal Justice

Illinois State University

Normal, IL 61790-5250

Corresponding author: Ralph Weisheit, 309-438-3849; raweish@ilstu.edu

\begin{abstract}
Much of the research on rural crime has focused on the U.S. In recent years, however, there has been a dramatic increase in rural crime research in other regions of the world. This paper will report the results of a systematic review of rural crime research conducted outside of the United States. The review identifies common themes, including the manner in which rural is defined, the types of crime examined, and the methodology employed.
\end{abstract}

\section{Keywords: rural crime, international}




\section{Introduction}

In the United States rural residents make up about 15 percent of the population, and globally the rural population constitutes about 46 percent of the world's population (World Health Organization, 2014). By any measure the number of people living in rural areas is large. Just as importantly, however, is that while most people live in urban areas, most places are rural. In the United States, for example, that 15 percent population figure covers 72 percent of the country's land area (Economic Research Service, 2014). Whether measured by the number of people or by the land area they occupy, rural is an important issue for study and rural crime is an important dimension of that issue.

Rural has practical utility regarding understanding crime and effectively responding to it. While the sheer number of crimes and criminals in urban areas simplifies the study of crime, the number of large urban areas is small compared to the number of rural areas. This large number of places includes wide variability on factors sometimes associated with crime. This wide variability makes the rural setting a good place to develop and test criminological theories and assumptions about crime (Donnermeyer, Barclay and Jobes 2002).

Rural areas vary widely one from another, whether their economies are based on agriculture, tourism, light manufacturing, service, or the extraction of natural resources. They vary widely in whether they have high or low levels of violence, and whether they are physically remote or adjacent to large urban centers. Rural areas vary in whether they are experiencing population growth or decline, and whether they have diverse or homogeneous ethnic and/or racial populations. Similarly, rural areas vary widely in the culture and customs that shape the operation of the criminal justice system.

An understanding of the forces that shape rural crime has important implications for understanding crime more generally. For example, theories that were developed utilizing urban settings don't always seem to apply equally well when applied to crime in rural areas. Weisheit and Wells (2005) found that variables traditionally associated with social disorganization theory accounted for a relatively high percentage of the variance in homicide rates in the largest urban areas. However, the ability of these variables to account for homicide rates declined precipitously as one examined progressively more rural areas. The variance explained by these indicators of traditional social disorganization theory dropped from .64 in the largest metropolitan areas to .17 in the most rural areas. When this happens the generalizability and ultimate utility of the theory is called into question. Further, it is not always clear what is meant by rural and what unit of analysis makes the most sense for rural. As Kaylen and Pridemore (2003, p. 920) have observed: 
"Our results indicate that levels of social disorganization in rural and urban communities are not similarly associated with the common structural antecedents posited by social disorganization theory. This necessitates either a more general theory that better explains crime rates in both types of communities, or a rural-specific model."

In short, there may be important ways in which rural crime and factors generating it are very different from crime in urban areas. These differences merit exploration and have implications for policy, practice, and theory.

\section{Purpose of the Study}

Much of the research on rural crime has centered on the United States. That research suggests some of the ways in which rural crime and justice are different in rural and urban areas. The research also suggests that theories of crime developed utilizing what is known about crime in urban areas may not fit the rural setting.

Research based on data from the United States has proven interesting and has broadened our understanding of rural crime and of theories of crime. However, only about four percent of the world's population lives in the United States (U.S. Census Bureau, 2014) and, as indicated above, the rural population is a much larger percentage of the population in the rest of the world compared with the United States (46 percent versus 15 percent). Further, the variability across rural areas within the United States that makes rural a valuable laboratory for the study of crime, is likely to be much greater when considering the global context. Although data from the United States have made considerable contributions to the study of rural crime, there has been a growing body of research in other countries. This study provides a systematic review of that research. A complete list of these international references can be found in Appendix A.

\section{Methodology}

This is a systematic review of the literature on rural crime outside of the United States. The literature was identified by conducting on-line searches using Sociological Abstracts, the SocINDEX, PAIS International, and Criminal Justice Abstracts. The search was limited to journal articles published between January 2000 and October of 2014. ${ }^{2}$ Search terms included "rural+crime" and was limited to English language articles. Articles on topics such as illicit drug use or drug treatment were included only if they specifically included a rural component. In addition, as articles were read the reference list of each article was checked for articles the electronic search might have missed.

Each identified article was read and coded on the following variables: Year of publication, page length, name of journal, country, number of countries included, how rural was defined, was 
there a comparison of rural and urban, if there was a rural-urban comparison and if either had higher crime levels, number of methods used, the primary methodology, if a theory was applied and if so which theory, the primary crime type, the number of authors, and the last name and first initial of each author.

\section{Questions About Classifying}

Like people, articles vary substantially one from another and not every one fits neatly into a distinct category. Deciding what to include proved a challenge. For example, an article about crime victimization in Namibia was excluded. It reported on the results of a national survey and in the article noted that the majority of the population lived in rural areas. However, the article did not further incorporate anything about rural in reporting its findings. It did include a brief mention of cattle theft but did so absent a discussion of the rural context. An article discussing the merits of a separate category of crime called conservation crime was excluded because there was no discussion of the rural nature of such crime. Other issues regarding categorizing also arose.

Watson's (2008) historical study of a woman who committed multiple infanticides was recorded as a violent crime rather than domestic violence. It was elected to include Häkkänen, Hurme and Liukkonen's (2007) study of homicide in Finland which reported on the disposal of bodies in rural areas, but did not elaborate on whether the offenses happened in rural or urban areas. In contrast, articles were included that did not explicitly identify their subjects as rural but did focus on farm crime or cattle theft. vanKempen's (2009) article title says the study is in rural Guatemala but their sample is $2 / 3$ urban and there is no distinction between urban and rural in their analysis. Despite its title it was excluded. Sukhai's (2000) study of rural residents who move to urban areas in China and commit crimes there also was excluded.

There was also a code for the presence of a theory, but different authors tended to utilize different ideas of what constituted a theory. While it might seem obvious, it is not always clear when a theory is applied to a rural crime problem. For example, Sidebottom (2013) uses Clark's notion of CRAVE to explain why cattle might be targeted for theft. In using CRAVE he notes:

"To be clear, CRAVED was never intended to be a theory of offender target selection. Instead, it was developed as a target-centered model to emphasize the attributes that thieves tend to favor, namely items that are concealable, removable, available, valuable, enjoyable, and disposable." (p. 198, emphasis in original).

Because the CRAVED model has much in common with routine activities it was recorded as such. 
There were also unique examples of methodology. For example, Smith's (2004) "case story method" used a fictional case to tell a story about a real crime by creating a composite based on actual cases. White's (2012) article on rural land theft is a conceptual piece describing the problem globally, but was recorded as a literature review.

\section{Findings}

As a result of the search process a total of 121 articles were found which addressed rural crime outside of the United States. A wide range of countries was represented among these articles. The final list included articles from 37 different countries, and a handful of studies $(n=5)$ that used global data. Antarctica was the only continent not represented in the studies. Australia and the United Kingdom were tied for the largest number of articles at 24 articles each (19.8\% each). Next in frequency was South Africa with 11 articles (9.1\%). The remainder were scattered across the globe from Bangladesh, to India, to Tanzania, to Pakistan.

The articles were found in a wide range of journals. These 121 articles were published in 81 different journals, including such outlets as The International Journal of Entrepreneurial Behaviour \& Research and The Journal of Technology Transfer. The most published journal in the area was Acta Criminologica with seven articles followed by The International Journal of Rural Criminology, in which six of the 121 articles were published. Three journals had four articles with the remaining journals having fewer, usually only one article.

Not only was a wide range of journals represented, but so was a wide range of authors. A total of 277 authors and co-authors were represented in the study, with about two-thirds of the articles $(66.1 \%)$ having only one or two authors. No one author dominated the literature.

\section{Defining Rural}

The first issue was how rural was defined in these studies. This is an issue with which researches, policy makers, and government agencies have struggled. Kaylen and Pridemore (2003, p. 920) note this concern in their own research:

“...definitions of 'rural' generally, and rural community more specifically, need to be more carefully considered. For example, neighbourhoods make sense as a unit of analysis in urban areas because social processes occur at this level and physical and social boundaries are fairly well defined. However, there is not currently an agreed upon definition of rural community. The units of analysis currently utilized - postcode sectors in this study and counties in many US studies - tend to be selected due to availability more so than their ability to represent rural community." 
Among these 121 articles the most common approach was to not define rural at all. In three quarters of the studies (74.4\%) the authors gave no specific measure of rural but used such vague descriptions as "a rural part of the country" or "rural villages." For some crimes this made logical sense, such as agricultural crimes or some wildlife crimes, depending on where in the process the research focused its attention. But these represented a minority of cases. Agricultural crimes, for example, were the focus of only 10.7 percent of the studies. Where more precise definitions were given they were based on either an established government classification $(13.2 \%)$ or a specified population size or density $(12.4 \%)$.

\section{Type of Crime}

As Table 1 shows, the research covered a variety of crime types, with a particular focus on crime in general and on violent crime. The least studied type of rural crime was property crime (not including agricultural crime), which accounted for only three of the 121 studies. Not every paper focused on a crime that fit neatly into one of these more conventional categories. Eleven of the articles focused on other types of crime, and the range of crime types represented in these articles demonstrates the value of looking beyond the boundaries of the United States. Among these "other" crimes were three studies of wildlife crime (Ceccato and Uittenbogaard, 2013; Kahler and Gore, 2012; Pires and Clarke, 2012) and one study each of software piracy (Goel and Nelson, 2009), illegal deforestation (Boekhout, 2010), unlicensed drivers (McDowell et al., 2009), dog fighting (Smith, 2011), fear of crime (Schuermans, 2010), the illegal harvesting of firewood (van Kempen et al., 2009), land theft (White, 2012), and illegal enterprises in general (McElwee et al., 2011).

\section{Table 1: Type of Crime Studied}

\begin{tabular}{lcc}
\multicolumn{1}{c}{ Type of Crime } & Number of Studies & Percent \\
\hline General/Multiple Types & 29 & 24.0 \\
Violent & 26 & 21.5 \\
Domestic Violence & 22 & 18.2 \\
Agricultural/Farm & 13 & 10.7 \\
Alcohol/Drugs & 10 & 8.3 \\
Sex Offenses & 7 & 5.8 \\
Property & 3 & 2.5 \\
Other & 11 & 9.1 \\
\hline Total & 121 & $100 \%$
\end{tabular}




\section{Comparing Rural and Urban}

Only $34(28 \%)$ of the articles made comparisons between urban and rural. Of those articles 10 reported lower incidents in rural areas, 7 reported no difference, and 13 reported higher crime rates in rural areas. Four studies reported mixed results. For example, Baciu's (2012) study of child abuse in Romania found higher rates for emotional abuse in urban areas but higher rates for physical abuse in rural areas. Similarly, Biermann et al.'s (2011) study of offending and victimization by the elderly in Germany reported that urban elderly were less likely than rural to be offenders but were more likely to be victims.

\section{Methods Used}

Most studies (75.2\%) used only one method, although 17 studies (14.1\%) combined three or more methods. Table 2 shows, the most common method was original survey research (31.4\%), followed by qualitative methods (19.0\%) and then in equal amounts by utilizing existing police/court data (16.5\%) and other existing data, such as government sponsored surveys of health $(16.5 \%)$.

\section{Table 2: Methodology Used}

\begin{tabular}{lcc}
\multicolumn{1}{c}{ Type of Crime } & Number of Studies & Percent \\
\hline Survey Research & 38 & 31.4 \\
Qualitative Research & 23 & 19.0 \\
Police/Court Data & 20 & 16.5 \\
Other Existing Data & 20 & 16.5 \\
Literature Review & 7 & 5.8 \\
Historical & 5 & 4.1 \\
Case Study & 1 & .8 \\
Experimental/Quasi-Experimental & 1 & .8 \\
Content Analysis & 1 & .8 \\
Other & 5 & 4.1 \\
\hline Total & 121 & $100 \%$
\end{tabular}

The "other" category included interviews with visitors to a rural clinic for HIV (Birdthistle et al. 2013), a feminist analysis of honor killings (Sev'er and Yurdakul 2001), a discussion of the various methodologies that might be appropriate for the study of rural crime (Bell and Hall, 2007), a theoretical discussion of illegal rural entrepreneurship (McElwee, Smith, and Somerville 2011), and a general discussion of trends in the theft of livestock and farm machinery (Jones 2012). 


\section{Theory}

Most studies were not guided by theory (76.0\%). Of the 29 studies utilizing a theory, the most common theory was routine activities $(n=8)$, social disorganization $(n=5)$, and theories based on gender differences $(n=4)$. There were 6 articles categorized as "Other." These included a range of approaches, some perhaps more a perspective than a theory, but a perspective that organized the study. These included authoritarian personality theory (Norris and Reeves 2013), circle theory from the field of geography (Kocsis, Cooksey, Irwin and Allen 2002), marginalization of the poor (Juska and Paulikas 2006), dowry violence and noncooperative model of bargaining and signaling (Bloch and Rao 2002), theorizing illicit rural enterprises (McElwee, Smith, and Somerville 2011), and social capital (Woodhouse, 2006).

\section{Limitations of the Study}

There are several limitations to this study. Missing from this strategy are rural books and book chapters (e.g., Mawby and Yarwood 2011). The study goes no farther back than 2000, omitting some potentially important research conducted in the 1990 s and earlier. The study also limits its focus to rural crime, omitting the many interesting studies of rural criminal justice. Finally, the research includes only English language articles.

\section{Conclusions}

The picture painted in this systematic review is of a subject still in its developmental stages. Theory was applied in only about a quarter of the studies. The bulk of the research is descriptive and the relatively frequent use of qualitative methods suggests the basic landscape of rural crime internationally is still being plotted. There are signs that the topic is increasingly recognized as worthy of study. Over the 15 years of articles included in this study, almost 40 percent were published in the last 3 and one half years. Although it was only begun in 2011, The International Journal of Rural Criminology yielded the second highest number of articles in this study. Further, 2014 marked the beginning of the International Journal of Rural Law and Policy. Although too new to have contributed articles for this study, the journal holds promise as an important outlet for future research.

There are other signs that the subject is in the early stages of study. One sign is that most (74\%) studies fail to specifically define rural, or to even make an attempt at definition. This is not a new problem but is one that may be even more complicated when applied internationally. Another sign is to describe rural crime without comparing it to urban crime in the same country. Such a comparison only occurred 28 percent of the time. Without some point of comparison it is difficult to determine whether rural crime is in fact distinct. 
Finally, there was a lack of comparison across countries. Only five studies used global data sets. This was not surprising given the problems associated with trying to have comparable measures and a comparable quality of data across a large number of countries. What was surprising was that only one study (Jobs 2006) compared rural conditions across two countries (Australia with Pakistan).

The study of rural crime has the potential to broaden our understanding of crime in general and that potential is only enhanced by conducting studies of rural crime in a range of countries. This systematic review suggests that important inroads are being made into a better understanding of rural crime from a global perspective.

\section{Endnote}

${ }^{1}$ An earlier version of this paper was presented to the Annual Meeting of the American Society of Criminology November 20, 2014 in San Francisco, California.

${ }^{2}$ My search does not include three special issues on rural crime, including Southern Rural Sociology (now, the Journal of Rural Social Sciences) (No 2, 2008, Volume 23), Critical Criminology (March, 2014 issue, Volume 22) and the Journal of Rural Studies (June, 2015, Volume 39). The JRS issue was based on a rural crime conference organized by Vania Ceccato, who is an Associate Professor at the Royal Institute of Technology (KTH), Stockholm, Sweden. The conference was held in September, 2014. 


\section{References}

Baciu, C., V. Corina, Imola, A., Elemér, M. and Roth, M. (2012). Abusive parents from rural and urban areas. Social Work Review, 11, 81-89.

Bell, E. and Hall, R. (2007). "Dead in the water": Is rural violent crime prevention floating facedown because criminology can't handle context? Crime Prevention and Community Safety, 9, 252-274, http://dx.doi.org/10.1057/palgrave.cpcs.8150051

Biermann, T., Dippel, O., Bergner, M., Keller, J., Coffey, C., Sperling, W., Bleich, S., Kornhuber, J. and Reulbach U. (2011). Assaults in the elderly-a population-based study with victim and perpetrator characteristics. Journal of Forensic Sciences, 56, 669-673, http://dx.doi.org/10.1111/j.1556-4029.2011.01712.x

Birdthistle, I., Mayanja, B., Maher, D., Floyd, S., Seeley, J. and Weiss, H. (2013) Nonconsensual sex and association with incident HIV infection among women: A cohort study in rural Uganda, 1990-2008. AIDS \& Behavior, 17, 2430-2438, http://dx.doi.org/10.1007/s10461-012-0378-8

Bloch, F. and Rao, V. (2002). Terror as a bargaining instrument: A case study of dowry violence in rural India. The American Economic Review, 92, 1029-1043, http://dx.doi.org/10.1257/00028280260344588

Boekhout, v. (2010) Deforestation crimes and conflicts in the Amazon. Critical Criminology, 18, 263-277, http://dx.doi.org/10.1007/s10612-010-9120-x

Ceccato, V. and Uittenbogaard. A. (2013). Environmental and wildlife crime in Sweden. International Journal of Rural Criminology, 2, 25-52.

Donnermeyer, J.F., Barclay, E.M. and Jobes, P.C. (2002). Drug-related offenses and the structure of communities in rural Australia. Substance Use \& Misuse, 37, 631-661, http://dx.doi.org/10.1081/JA-120004277

Economic Research Service. (2014) USDA ERS - Population \& Migration. Retrieved 11/11/14 from http://www.ers.usda.gov/topics/rural-economy-population/populationmigration.aspx

Goel, R. and Nelson, M.A. (2009) Determinants of software piracy: Economics, institutions, and technology. The Journal of Technology Transfer, 34, 637-658, http://dx.doi.org/10.1007/s10961-009-9119-1 
Häkkänen, H., Hurme, K. and Liukkonen, M. (2007). Distance patterns and disposal sites in rural area homicides committed in Finland. Journal of Investigative Psychology \& Offender Profiling, 4, 181-197, http://dx.doi.org/10.1002/jip.77

Jobes, P.C. (2006). Victimisation and perceptions that crime is a problem: An empirical comparison of rural Pakistan and Australia. Australasian Journal of Regional Studies, $12,21-45$.

Jones, J. (2012). Looking beyond the "rural idyll": Some recent trends in rural crime. Criminal Justice Matters, 89, 8-9, http://dx.doi.org/10.1080/09627251.2012.721964

Juska, A. and Paulikas, V. (2006) Rural marginalization, policing, and crime in Lithuania. Police Practice \& Research, 7, 431-447, http://dx.doi.org/10.1080/15614260601076066

Kahler, J. and Gore, M.L. (2012). Beyond the cooking pot and pocket book: Factors influencing noncompliance with wildlife poaching rules. International Journal of Comparative and Applied Criminal Justice, 36, 103-120, http://dx.doi.org/10.1080/01924036.2012.669913

Kaylen, M.T. and Pridemore, W.A. (2013). Social disorganization and crime in rural communities. British Journal of Criminology, 53, 905-923, http://dx.doi.org/10.1093/bjc/azt031

Kocsis, R.N., Cooksey, R.W., Irwin, H. and Allen, G. (2002) A further assessment of 'circle theory' for geographic psychological profiling. Australian \& New Zealand Journal of Criminology, 35, 43-62, http://dx.doi.org/10.1375/acri.35.1.43

Mawby, R.I. and Yarwood, R. (Eds.) (2011). Rural policing and policing the rural: A constable countryside? Burlington, VT: Ashgate Publishing.

McDowell, A., Begg, D., Connor, J. and Broughton, J. (2009). Unlicensed driving among urban and rural Maori drivers: New Zealand drivers study. Traffic Injury Prevention, 10, 538545, http://dx.doi.org/10.1080/15389580903321727

McElwee, G., Smith, R. and Somerville, P. (2011). Theorising illegal rural enterprise: Is everyone at it? International Journal of Rural Criminology, 1, 40-62.

Norris, G. and Reeves, H. (2013). Fear of crime and authoritarianism: A comparison of rural and urban attitudes. Crime Prevention \& Community Safety, 15, 134-150, http://dx.doi.org/10.1057/cpcs.2013.2 
Pires, S. and Clarke, R. (2012) Are parrots CRAVED? An analysis of parrot poaching in Mexico. Journal of Research in Crime and Delinquency, 49, 122-146, http://dx.doi.org/10.1177/0022427810397950

Schuermans, N. (2010). Fear of crime as a political weapon: Explaining the rise of extreme right politics in the Flemish countryside. Social \& Cultural Geography, 11, 247-262, http://dx.doi.org/10.1080/14649361003637190

Sev'er, A. and Yurdakul, G. (2001). Culture of honor, culture of change: A feminist analysis of honor killing in rural Turkey. Violence Against Women, 7, 964-999, http://dx.doi.org/10.1177/10778010122182866

Sidebottom, A. (2013). On the application of CRAVED to livestock theft in Malawi. International Journal of Comparative \& Applied Criminal Justice, 37, 195-212, http://dx.doi.org/10.1080/01924036.2012.734960

Smith, R. (2004). Rural rogues: A case story on the 'smokies' trade. International Journal of Entrepreneurial Behaviour \& Research, 10, 77-294, http://dx.doi.org/10.1108/13552550410544231

Smith, R. (2011) Investigating financial aspects of dog-fighting in the UK. Journal of Financial Crime, 18, 336-346, http://dx.doi.org/10.1108/13590791111173687

Shukai, Z. (2000). Criminality and the policing of migrant workers. China Journal, 43, 101-110, http://dx.doi.org/10.2307/2667534

U.S. Census Bureau. (2014). U.S. and World Population Clock. Retrieved 11/11/14 from: http://www.census.gov/popclock/

van Kempen, L., Muradian, R., Sandoval, C. and Castaneda, J.P. (2009) Analysis: Too poor to be green consumers? A field experiment on revealed preferences for firewood in rural Guatemala. Ecological Economics, 68, 2160-2167, http://dx.doi.org/10.1016/j.ecolecon.2009.02.014

Watson, K.D. (2008). Religion, community and the infanticidal mother: Evidence from 1840s rural Wiltshire. Family \& Community History, 11, 116-133, http://dx.doi.org/10.1179/175138108X355148

Weisheit, R.A. and Wells, L.E. (2005) Deadly violence in the heartland: Comparing homicide patterns in nonmetropolitan and metropolitan counties. Homicide Studies, 9, 55-80, http://dx.doi.org/10.1177/1088767904271434 
White, R. (2012). Land theft as rural eco-crime. International Journal of Rural Criminology, 1, 203-217.

Woodhouse, A. (2006) "People are accepted as long as they don't misbehave": Exploring the relationship between social capital and crime in rural Australia. Rural Society, 16, 5-24, http://dx.doi.org/10.5172/rsj.351.16.1.5

World Health Organization. (2014). Global Health Observatory: Urban Population Growth. Retrieved 11/11/14 from http://www.who.int/gho/urban_health/situation_trends/urban_population_growth_text/en/ 


\section{Appendix A: 121 International References about Rural Crime}

Anscombe, A.W. (2010). Indigenous rural identity in Australia: From tribesman to prisoner. Rural Society, 20 (supplemental), 43-57.

Attari, M.A., Asgary, S., Shahrokhi, S., Naderi, G.A., and Shariatirad, S. (2012). Cannabis and opium abuse patterns and their associated complications in a sample of young Iranians. Journal of Child and Adolescent Substance Abuse, 21, 238-246, http://dx.doi.org/10.1080/1067828X.2012.689806

Baciu, C., Corina, V., Antal, M., Mezi, E., and Roth, Maria. (2012). Abusive parents from rural and urban areas. Social Work Review, 11, 81-89,

Ball, H.N. (2008). Sexual offending against older female victims: An empirical study of the prevalence and characteristics of recorded offences in a semi-rural English county. Journal of Forensic Psychiatry \& Psychology, 19, 14-32, http://dx.doi.org/10.1080/14789940701561750

Barclay, E.M., and Donnermeyer, J.F. (2002). Property crime victimisation and crime prevention on farms in Australia. Crime Prevention \& Community Safety: An International Journal, 4, 47-61, http://dx.doi.org/10.1057/palgrave.cpcs.8140169

Barclay, E. (2003). The determinants of reporting farm crime in Australia. International Journal of Comparative and Applied Criminal Justice, 27, 131-151, http://dx.doi.org/10.1080/01924036.2003.9678706

Barclay, E.M., Donnermeyer, J.F., and Jobes, P.C. (2004). The dark side of gemeinschaft: Criminality within rural communities. Crime Prevention \& Community Safety: An International Journal, 6, 7-22, http://dx.doi.org/10.1057/palgrave.cpcs.8140191

Barclay, E.M., and Donnermeyer, J.F. (2011). Crime and security on agricultural operations. Security Journal, 24, 1-18, http://dx.doi.org/10.1057/sj.2008.23

Bell, E., and Hall, R. (2007). "Dead in the water": Is rural violent crime prevention floating facedown because criminology can't handle context? Crime Prevention \& Community Safety: An International Journal, 9: 252-274, http://dx.doi.org/10.1057/palgrave.cpcs.8150051

Biermann, T., Dippel, O, Bergner, M., Keller, J., Coffey, C., Sperling, W., Bleich, S., Kornhuber, J., and Reulbach, U. (2011). Assaults in the elderly - a population-based study with victim and perpetrator characteristics. Journal of Forensic Sciences, 56, 669-673. 
Birdthistle, I., Mayanja B., Maher, D., Floyd, S., Seeley, J., and Weiss, H. (2013). Nonconsensual sex and association with incident HIV infection among women: A cohort study in rural Uganda, 1990-2008. AIDS \& Behavior, 17, 2430-2438, http://dx.doi.org/10.1007/s10461-012-0378-8

Bloch, F. and Rao, V. (2002) Terror as a bargaining instrument: A case study of dowry violence in rural India. The American Economic Review, 92, 1029-1043, http://dx.doi.org/10.1257/00028280260344588

Boekhout van S.T. (2010). Deforestation crimes and conflicts in the Amazon. Critical Criminology, 18, 263-277, http://dx.doi.org/10.1007/s10612-010-9120-x

Boswell, G., Poland F., Killett, A., Cross, J. (2009). A research basis for addressing youth offending on the Broadland "Stairway Out of Crime" programme. British Journal of Community Justice, 7, 53-64.

Brownridge, D. A. (2003). Male partner violence against Aboriginal women in Canada: An empirical analysis. Journal of Interpersonal Violence, 18, 65-83, http://dx.doi.org/10.1177/0886260502238541

Brownridge, D.A. (2009). A comparison of partner violence against women in rural and urban Canada - prevalence, correlates, consequences, and help-seeking behavior. Family \& Intimate Partner Violence Quarterly, 1, 307-325.

Bunei, E., Rono, J.K., and Chessa S.R. (2013). Factors influencing farm crime in Kenya: Opinions and experiences of farmers. International Journal of Rural Criminology, 2, 75100.

Carcach, C. (2000). Regional development and crime. Trends \& Issues in Crime \& Criminal Justice, 160, 1-6.

Carrington, K. and Scott, J. (2008). Masculinity, rurality and violence. British Journal of Criminology, 48, 641-666, http://dx.doi.org/10.1093/bjc/azn031

Carrington, K., McIntosh, A., Hogg, R., Scott, J. (2013). Rural masculinities and the internalization of violence in agricultural communities. International Journal of Rural Criminology, 2, 3-24.

Ceccato V., and Dolmen, L. (2011). Crime in rural Sweden. Applied Geography, 31, 119-135, http://dx.doi.org/10.1016/j.apgeog.2010.03.002

Ceccato, V. and Dolmen, L. (2013). Crime prevention in rural Sweden. European Journal of Criminology, 10, 89-112, http://dx.doi.org/10.1177/1477370812457763

Ceccato, V., and Uittenbogaard, A. (2013). Environmental and wildlife crime in Sweden. International Journal of Rural Criminology, 2, 25-52. 
Clack, W. (2013). The extent of stock theft in South Africa. Acta Criminologica. 26, 77-91.

Davis, K., Taylor B., and Furniss, D. (2001). Narrative accounts of tracking the rural domestic violence survivors' journey: A feminist approach. Health Care for Women International, 22, 333-347.

Deng, Q., Tang, Q., Schottenfeld, R.S., Hao, W., and Chawarski, M.C. (2011). Drug use in rural China: A preliminary investigation in Hunan Province. Addiction, 107, 610-613, http://dx.doi.org/10.1111/j.1360-0443.2011.03648.x

Denney, D., Gabe, J., and O'Bierne, M. (2008). Anglican clergy victims of routinized violent activities in urban and rural localities. Sociology, 42, 83-99, http://dx.doi.org/10.1177/0038038507084826

Donnermeyer, J.F., Barclay, E.M., and Jobes, P.C. (2002). Drug-related offenses and the structure of communities in rural Australia. Substance Use \& Misuse, 37, 631-661, http://dx.doi.org/10.1081/JA-120004277

Donnermeyer, J.F. and Barclay, E.M. (2005). The policing of farm crime. Police Practice and Research, 6, 3-17, http://dx.doi.org/10.1080/15614260500046913

Doucet, D., and Denov, M. (2012). The power of sweet words: Local forms of intervention with war-affected women in rural Sierra Leone. International Social Work, 55, 612-628, http://dx.doi.org/10.1177/0020872812447639

Drugge, U. (2009). Crime and psychiatry in problematic coexistence: Four domestic homicides and the nineteenth-century courts. Journal of Scandinavian Studies in Criminology \& Crime Prevention, 10, 55-74, http://dx.doi.org/10.1080/14043850902815099

Fattah, K.N., and Kabir, Z.N. (2013). No place is safe: Sexual abuse of children in rural Bangladesh. Journal of Child Sexual Abuse, 22, 901-914, http://dx.doi.org/10.1080/10538712.2013.841310

Fiki, C. (2007). Globalization and drug and alcohol use in rural communities in Nigeria: A case study. Journal of Sociology \& Social Welfare, 34, 36-56.

Frischer, M., Anderson, S., Hickman, M., and Heatlie, H. (2002). Diffusion of drug misuse in Scotland: Findings from the 1993 and 1996 Scottish crime surveys. Addiction Research \& Theory, 10, 83-95.

Garland, J., and Chakraborti, N. (2004). Racist victimization, community safety and the rural: Issues and challenges. British Journal of Community Justice, 2, 21-32. 
Goel, R., and Nelson, M.A. (2009). Determinants of software piracy: Economics, institutions, and technology. The Journal of Technology Transfer, 34, 637-658, http://dx.doi.org/10.1007/s10961-009-9119-1

Hackett, M. (2011). Domestic violence against women: Statistical analysis of crimes across India. Journal of Comparative Family Studies, 42, 267-288,

Häkkänen, H., Hurme, K., and Liukkonen, M. (2007). Distance patterns and disposal sites in rural area homicides committed in Finland. Journal of Investigative Psychology \& Offender Profiling, 4, 181-197, http://dx.doi.org/10.1002/jip.77

Hess, K., and Waller, L. (2012). "The Snowtown we know and love": Small newspapers and heinous crimes. Rural Society, 21, 116-125, http://dx.doi.org/10.5172/rsj.2012.21.2.116

Hilal, S. M., Densley, J.A., Li, S.D., and Ma, Y. (2014) The routine of mass murder in China. Homicide Studies, 18, 83-104, http://dx.doi.org/10.1177/1088767913505092

Hraba, J., Lorenz, F.O, and Radloff, T. (2002). Czechs experiencing crime: Rural-urban differences in the perceived risk of crime, fear of crime, and victimization. International Journal of Contemporary Sociology, 39, 69-90.

Homma, Y., Nicholson, D. and Saewyc, E.M. (2012). A profile of high school students in rural Canada who exchange sex for substances. Canadian Journal of Human Sexuality, 21, 2940.

Jewkes, R., Dunkle, K., Koss, M.P., Levin, J.B., Nduna, M., Jama, N., and Sikweyiya, Y. (2006). Rape perpetration by young, rural South African men: Prevalence, patterns and risk factors. Social Science \& Medicine, 63, 2949-2961, http://dx.doi.org/10.1016/j.socscimed.2006.07.027

Jewkes, R., Dunkle, K., Nduna, M., Jama, N., and Puren, A. (2010). Associations between childhood adversity and depression, substance abuse and HIV and HSV2 incident infections in rural South Africa. Child Abuse \& Neglect, 34, 833-841, http://dx.doi.org/10.1016/j.chiabu.2010.05.002

Jobes, P.C., Barclay, E., Donnermeyer, J.F., and Graycar, A. (2001). Rural crime in Australia: Contemporary concerns, recent research and future directions. Australasian Journal of Regional Studies, 7, 3-21.

Jobes, P.C. (2004). Colonization and crime: Contemporary consequences of invasion of indigenous peoples in rural places. International Review of Sociology, 14, 51-71, http://dx.doi.org/10.1080/0390670042000186761

Jobes, PC., Barclay, E., Weinand, H., and Donnermeyer, J.F. (2004). A structural analysis of social disorganization and crime in rural communities in Australia. Australian \& New Zealand Journal of Criminology, 37, 114-140, http://dx.doi.org/10.1375/acri.37.1.114 
Jobes, P.C., Donnermeyer, J.F., and Barclay, E. (2005). A tale of two towns: Social structure, integration and crime in rural New South Wales. Sociologia Ruralis, 45, 224-244, http://dx.doi.org/10.1111/j.1467-9523.2005.00302.x

Jobes, P.C. (2006). Victimisation and perceptions that crime is a problem: An empirical comparison of rural Pakistan and Australia. Australasian Journal of Regional Studies, 12, $21-45$.

Jones, J. (2008). "The good old days": In-migration, social control and the decline of the 'imagined' community in a north Wales market town. Community, Work \& Family, 11, 19-36, http://dx.doi.org/10.1080/13668800701785304

Jones, J. (2010). The neglected problem of farm crime: An exploratory study." Safer Communities, 9, 36-44, http://dx.doi.org/10.5042/sc.2010.0013

Jones, J. (2012). Looking beyond the "rural idyll": Some recent trends in rural crime. Criminal Justice Matters, 89, 8-9, http://dx.doi.org/10.1080/09627251.2012.721964

Juska, A., and Paulikas, P. (2006). Rural marginalization, policing, and crime in Lithuania. Police Practice \& Research, 7, 431-447, http://dx.doi.org/10.1080/15614260601076066

Kahler, J., and Gore, M.L. (2012). Beyond the cooking pot and pocket book: Factors influencing noncompliance with wildlife poaching rules. International Journal of Comparative and Applied Criminal Justice, 36, 103-120, http://dx.doi.org/10.1080/01924036.2012.669913

Kaimba, G.K., Njehia, B.K., and Guliye, A.Y. (2011). Effects of cattle rustling and household characteristics on migration decisions and herd size among pastoralists in Baringo District, Kenya. Pastoralism: Research, Policy and Practice, 1, 1-16.

Kapoor, D. (2007). Gender-caste violations and the cultural politics of voice in rural Orissa, India. Gender, Place \& Culture: A Journal of Feminist Geography, 14, 609-616, http://dx.doi.org/10.1080/09663690701562453

Karstedt, S, (2000). Emancipation, crime and problem behavior of women: A perspective from Germany. Gender Issues, 18, 21-58, http://dx.doi.org/10.1007/s12147-000-0016-z

Kaylen, M.T. and Pridemore, W.A. (2013). Social disorganization and crime in rural communities. British Journal of Criminology, 53, 905-923, http://dx.doi.org/10.1093/bjc/azt031

Kocsis, R.N., Cooksey, R.W., Irwin, H., and Allen, G. (2002). A further assessment of 'circle theory' for geographic psychological profiling. Australian \& New Zealand Journal of Criminology, 35, 43-62, http://dx.doi.org/10.1375/acri.35.1.43

Koenig, M.A., Ahmed, S., Hossain, M.B., and Mozumder, A.K.A. (2003). Women's status and domestic violence in rural Bangladesh: Individual and community-level effects. Demography, 40, 269-288, http://dx.doi.org/10.1353/dem.2003.0014 
Koenig, M.A., Lutalo, T., Zhao, F., Nalugoda, F., Wabwire-Mangen, F., Kiwanuka, N., Wagman, J., Serwada, D., Wawer, M., and Gray, R. (2003). Domestic violence in rural Uganda: Evidence from a community-based study. Bulletin of the World Health Organization, 81, 53-60.

Kotzé, N., and Strydom, H. (2007). Farm workers' perception concerning poverty and crime: A supporting literature review. Acta Criminologica, 20, 102-118.

Krishnan, S. (2005). Gender, caste, and economic inequalities and marital violence in Rural South India. Health Care for Women International, 26, 87-99, http://dx.doi.org/10.1080/07399330490493368

Krishnan, S. (2005). Do structural inequalities contribute to marital violence? Ethnographic evidence from rural South India. Violence Against Women, 11, 759-775, http://dx.doi.org/10.1177/1077801205276078

Leloup, P., Rousseaux, X., and Vrints, A. (2014). Banditry in occupied and liberated Belgium, 1914-21: Social practices and state reactions. Social History, 39, 83-105, http://dx.doi.org/10.1080/03071022.2014.885777

Maldonado A.S. (2013). Stories of drug trafficking in rural Mexico: Territories, drugs and cartels in Michoacan. European Review of Latin American and Carribean Studies, 94, 43-66, http://dx.doi.org/10.18352/erlacs.8393

Marsh, J.A., and Moohan, J.A. (2003). Small firms in rural areas: Experiences of victimization. Security Journal, 16, 39-49, http://dx.doi.org/10.1057/palgrave.sj.8340124

Martire, K.A., and Larney, S. (2011). Health outcomes, program completion, and criminal recidivism among participants in the Rural Alcohol Diversion program. Journal of Substance Use, 16, 50-56, http://dx.doi.org/10.3109/14659891003706407

Mathews, S., Abrahams, N., Jewkes, R., Martin, L.J., Lombard, C. (2009). Alcohol use and its role in female homicides in the Western Cape, South Africa. Journal of Studies on Alcohol \& Drugs, 70, 321-327, http://dx.doi.org/10.15288/jsad.2009.70.321

Mawby, R.I. (2003). Conducting crime audits in a rural county of England: Processes and outputs. International Journal of Police Science \& Management, 5, 161-179, http://dx.doi.org/10.1350/ijps.5.3.161.16065

Mawby, R.I. (2003). Crime and the business community: Experiences of businesses in Cornwall, England. Security Journal, 16, 45-61, http://dx.doi.org/10.1057/palgrave.sj.8340145

Mawby, R.I., and Jones, C. (2004). Explaining patterns of victimization within a rural county of England. International Criminal Justice Review, 14, 99-123, http://dx.doi.org/10.1177/105756770401400105 
McConnell, R., and Mullins S. (2004). "We had both been drinking since Christmas": Battered wives and dead abusive husbands in early colonial Rockhampton, Journal of Australian Colonial History, 5, 100-19.

McDowell, A., Begg, D., Connor, J., and Broughton, J. (2009). Unlicensed driving among urban and rural Maori drivers: New Zealand drivers study. Traffic Injury Prevention, 10, 538545.

McElwee, G., Smith, R., and Somerville, P. (2011). Theorising illegal rural enterprise: Is everyone at it? International Journal of Rural Criminology, 1, 40-62.

Meek, R. (2006). Social deprivation and rural youth crime: Young men in prison and their experiences of the "rural idyll." Crime Prevention \& Community Safety: An International Journal, 8, 90-103, http://dx.doi.org/10.1057/palgrave.cpcs.8150006

Meneses, R. and Fondevila, G. (2014). Mapping the killer state: Gender, space, and deaths due to legal intervention in Mexico (2004-2010). Women \& Criminal Justice, 24, 306-323, http://dx.doi.org/10.1080/08974454.2014.890159

Miguel, E. (2005). Poverty and witch killing. Review of Economic Studies, 72, 1153-1172, http://dx.doi.org/10.1111/0034-6527.00365

Mkhize, S., Gopal, N., and Collings, S.J. (2012) The impact of community violence on learners: A study of school in the Swayimana rural area. Acta Criminologica (Special Edition), 3845 .

Moolman, N. (2000). Farm attacks: Are there any ulterior motives? Acta Criminologica, 13, 6474.

Ndetei, D.L., Khasakhala, I., Mutiso, V., Ongecha-Owuor, F.A., and Kokonya, D.A. (2010). Drug use in a rural secondary school in Kenya. Substance Abuse, 31, 170-173, http://dx.doi.org/10.1080/08897077.2010.495313

Nhundu, T.J. and Shumba, A. (2001). The nature and frequency of reported cases of teacher perpetrated child sexual abuse in rural primary schools in Zimbabwe. Child Abuse \& Neglect, 25, 1517-1534, http://dx.doi.org/10.1016/S0145-2134(01)00288-5

Nomiya, D., Miller, A.S., Hoffmann, J.P., Nalla, M.K. (2000) Urbanization and rural depletion in modern Japan: An analysis of crime and suicide patterns. International Journal of Comparative \& Applied Criminal Justice, 24, 1-18, http://dx.doi.org/10.1080/01924036.2000.9678649

Norris, G., and Reeves, H. (2013). Fear of crime and authoritarianism: A comparison of rural and urban attitudes. Crime Prevention \& Community Safety, 15, 134-150, http://dx.doi.org/10.1057/cpcs.2013.2 
Odero, M., Hatcher, A.M., Bryant, C., Onono, M., Romito, P., Bukusi, E.A., and Turan, J.M. (2014). Responses to and resources for intimate partner violence: Qualitative findings from women, men, and service providers in rural Kenya. Journal of Interpersonal Violence, 29, 783-805, http://dx.doi.org/10.1177/0886260513505706

Olivier, J., and Cunningham, P. (2006). Victim's perception of attacks on farms and smallholdings in the Eastern Cape, South Africa. Acta Criminologica, 19, 115-126.

Ononokpono, D.N., and Azfredrick, E.C. (2014). Intimate partner violence and the utilization of maternal health care services in Nigeria. Health Care for Women International, 35, 973989, http://dx.doi.org/10.1080/07399332.2014.924939

Panda, P., and Agarwal, A. (2005). Marital violence, human development and women's property status in India. World Development, 33, 823-850, http://dx.doi.org/10.1016/j.worlddev.2005.01.009

Phaswana-Mafuya, N., and Ramalepe, M. (2008). Experience of abuse among women in a rural subdistrict of Limpopo province, South Africa. Acta Criminologica, 21, 46-55.

Pires, S., and Clarke, R. (2012). Are parrots CRAVED? An analysis of parrot poaching in Mexico. Journal of Research in Crime and Delinquency, 49, 122-146, http://dx.doi.org/10.1177/0022427810397950

Prakash, N. (2011). Domestic violence against women in rural Rajasthan, India: A sociological analysis. Research in Political Sociology, 19, 89-102, http://dx.doi.org/10.1108/S08959935(2011)0000019010

Putt, J., and Delahunty, B. (2006). Illicit drug use in rural and remote Indigenous communities. Trends \& Issues in Crime \& Criminal Justice, 322, 1-6.

Ragusa, A.T. (2013). Rural Australian women's legal help seeking for intimate partner violence: Women intimate partner violence victim survivors' perceptions of criminal justice support services. Journal of Interpersonal Violence, 28, 685-717, http://dx.doi.org/10.1177/0886260512455864

Roelofse, C., and Helm, A.H. (2012). Rural safety in South Africa: A study on rural selfprotection units in the Soutpansberg area Limpopo, South Africa, Internal Security, 4, 191214.

Rowe, S., Wiggers, J., Kingsland, M., Nicholas, C., and Wolfenden, L. (2012). Alcohol consumption and intoxication among people involved in police-recorded incidents of violence and disorder in non-metropolitan New South Wales, Australian \& New Zealand Journal of Public Health, 36, 33-40, http://dx.doi.org/10.1111/j.1753-6405.2011.00773.x

Saffitz, J. (2010). Understanding gender-based violence: Evidence from Kilimanjaro assessment of Rombo and Moshi rural. African Sociological Review, 14, 84-101. 
Schuermans, N. (2010). Fear of crime as a political weapon: Explaining the rise of extreme right politics in the Flemish countryside. Social \& Cultural Geography, 11, 247-262, http://dx.doi.org/10.1080/14649361003637190

Sev'er, A., and Yurdakul, G. (2001) Culture of honor, culture of change: A feminist analysis of honor killing in rural Turkey. Violence Against Women, 7, 964-999, http://dx.doi.org/10.1177/10778010122182866

Sidebottom, A. (2013). On the application of CRAVED to livestock theft in Malawi. International Journal of Comparative \& Applied Criminal Justice, 37, 195-212, http://dx.doi.org/10.1080/01924036.2012.734960

Smith, R. (2004). "Rural rogues: A case story on the 'smokies' trade." International Journal of Entrepreneurial Behaviour \& Research, 10(4): 277-294, http://dx.doi.org/10.1108/13552550410544231

Smith, R. (2011). Investigating financial aspects of dog-fighting in the UK, Journal of Financial Crime, 18, 336-346, http://dx.doi.org/10.1108/13590791111173687

Smith, R., and McElwee, G. (2013). Confronting social constructions of rural criminality: A case story of 'illegal pluriactivity' in the farming community, Sociologia Ruralis, 53, 112-134, http://dx.doi.org/10.1111/j.1467-9523.2012.00580.x

Smith, R. (2013). Developing a working typology of rural criminals: From a UK police intelligence perspective, International Journal of Rural Criminology, 2, 126-145.

Stephenson, R., Winter, A., and Hindin, M. (2013). Frequency of intimate partner violence and rural women's mental health in four Indian states, Violence Against Women, 19, 11331150, http://dx.doi.org/10.1177/1077801213501898

Stickley, A., Leinsalu, M. and Razvodovsky, Y.E. (2008). Homicide in post-Soviet Belarus: Urban-rural trends, European Journal of Public Health, 19, 117-120, http://dx.doi.org/10.1093/eurpub/ckn124

Sukhera, J., Cerjulli, C., Gawinski, B., and Morse, D. (2012). Bridging prevention and health: Exploring community perceptions of intimate partner violence in rural Honduras, Journal of Family Violence, 27, 707-714, http://dx.doi.org/10.1007/s10896-012-9454-0

Swart, D. (2000). Farm attacks in South Africa - Incidence and explanation, Acta Criminologica, $16,64-74$.

Taylor, L.R. (2005). Dangerous trade-offs: The behavioral ecology of child labor and prostitution in rural northern Thailand, Current Anthropology, 46, 411-431, http://dx.doi.org/10.1086/430079 
van Dun, M. (2014). Exploring narco-sovereignty/violence: Analyzing illegal networks, crime, violence, and legitimation in a Peruvian cocaine enclave (2003-2007), Journal of Contemporary Ethnography, 43, 395-418, http://dx.doi.org/10.1177/0891241613520452

Vung, N., Per-Olof O., and Krantz, G. (2009). Intimate partner violence against women, health effects and health care seeking in rural Vietnam, European Journal of Public Health, 19, 178-182, http://dx.doi.org/10.1093/eurpub/ckn136

Wallace, C., Galloway, T., McKetin, R., Kelly, E., Leary, J. (2009). Methamphetamine use, dependence and treatment access in rural and regional North Coast of New South Wales, Australia, Drug and Alcohol Review, 28, 592-599, http://dx.doi.org/10.1111/j.14653362.2008.00016.x

Watson, K.D. (2008). Religion, community and the infanticidal mother: Evidence from 1840s rural Wiltshire, Family \& Community History, 11, 116-133, http://dx.doi.org/10.1179/175138108X355148

Weenink, D. (2011). Delinquent behavior of Dutch rural adolescents, Journal of Youth \& Adolescence, 40, 1132-1146, http://dx.doi.org/10.1007/s10964-011-9650-x

White, R. (2012). Land theft as rural eco-crime, International Journal of Rural Criminology, 1 , 203-217.

Woodhouse, A. (2006) "People are accepted as long as they don't misbehave": Exploring the relationship between social capital and crime in rural Australia, Rural Society, 16, 5-24.

Yanqiu, G., Yan W., and Lin, A. (2011). Suicidal ideation and the prevalence of intimate partner violence against women in rural Western China, Violence Against Women, 17, 1299-1312, http://dx.doi.org/10.1177/1077801211425217

Yarwood, R., and Gardner, G. (2000). Fear of crime, cultural threat and the countryside, Area, 32, 403-411, http://dx.doi.org/10.1111/j.1475-4762.2000.tb00156.x

Yarwood, R. (2001). Crime and policing in the British countryside: Some agendas for contemporary geographical research, Sociologia Ruralis, 41, 201-219, http://dx.doi.org/10.1111/1467-9523.00178

Yarwood, R. (2005). Crime concern and policing in the countryside: Evidence from Parish councilors in West Mercia Constabulary, England, Policing \& Society, 15, 63-82, http://dx.doi.org/10.1080/1043946042000338931

Yarwood, R. (2010). An exclusive countryside? Crime concern, social exclusion and community policing in two English villages, Policing \& Society, 20, 61-78, http://dx.doi.org/10.1080/10439461003611500 
Rural Crime from A Global Perspective - Weisheit

Yen, C.F., Yang, M.S., Yang, M.J., Su, Y.C., Wang, M.H., and Lan, C.M. (2008) Childhood physical and sexual abuse: Prevalence and correlates among adolescents living in rural Taiwan, Child Abuse \& Neglect, 32, 429-438,

http://dx.doi.org/10.1016/j.chiabu.2007.06.003 